\title{
Metacognition and Integrated-Project Based Learning (I-PjBL) in Elementary Schools
}

\author{
Ika Maryani ${ }^{1, *}$, Dea Retno Putri ${ }^{1}$, Siti Urbayatun ${ }^{2}$, Suyatno $^{3}$, Caraka Putra Bhakti ${ }^{4}$ \\ ${ }^{1}$ Elementary School Education, Ahmad Dahlan University, Indonesia \\ ${ }^{2}$ School of Psychology, Ahmad Dahlan University, Indonesia \\ ${ }^{3}$ Education Management, Ahmad Dahlan University, Indonesia \\ ${ }^{4}$ Guidance and Counseling, Ahmad Dahlan University, Indonesia
}

Received December 8, 2019; Revised January 19, 2020; Accepted February 7, 2020

Copyright $\bigcirc 2020$ by authors, all rights reserved. Authors agree that this article remains permanently open access under the terms of the Creative Commons Attribution License 4.0 International License

\begin{abstract}
Metacognition is a skill closely related to learning and reflective behavior utilizing Integrated-project based learning (I-PjBL) as an alternative method. This study aimed to determine the effect of I-PjBL on the metacognition skill of elementary school students. The metacognition skills in this study are divided into two categories, namely knowledge and regulated cognition, therefore, the effect of IPjBL is measured for both. It was a quasi-Experimental study, which utilized the Single-Group Pre-Post-Test along with a simple random sampling method to obtain data. The subjects were 33 fifth grade students of Muhammadiyah Ambarbinangun Elementary school, with an observation guide used to examine the implementation of I-PjBL, and Metacognition Awareness Inventory (MAI). Furthermore, a documentation checklist was used to ensure the suitability of the learning process and its plan with different I-PjBL projects which was conducted four times. The first question was analyzed using descriptive statistic, while two-Wilcoxon Signed Ranks Test was used for the second and Mann-Whitney U for the third. The findings showed the difference in metacognition skills before and after the I-PjBL intervention, with no difference in knowledge and regulated cognition. However, some differences were found in the metacognition skill, knowledge, and regulated cognition of male and female students. Besides being affected by external factors (intervention of the I-PjBL model), Metacognition skill was also affected by internal factors such as motivation, thinking and learning style. In implementing I-PjBL, support from students and teachers, effective teamwork, teacher instruction, self-assessment skill and students' independence should be put into consideration.
\end{abstract}

Keywords I-PjBL, Metacognition, Knowledge, Regulated, Male, Female

\section{Introduction}

Teachers play an important role in providing various competencies for students, therefore, it is essential that they have expertise in learning innovation, possess good counseling skills, and comprehend students' improvement. Furthermore, students need to be able to follow the latest changes in educational curriculum development, integrate technology during the learning process, and internalize positive character [1]. Documented problems associated with learning in the $21^{\text {st }}$ century indicates that teachers need to create material to develop the critical thinking skills of students in order to achieve high metacognition knowledge. These skills enable students to think critically and also possess reflective behavior.

A metacognition study is defined as a self-awareness study of peoples' skills, and intends to train students to be self-directed learners [2]. It consists of cognition and regulated metacognition comprised of knowledge and experience [3]. The students tend to use a particular strategy to assess their self-awareness by determining their learning duration and choosing an effective way to solve a designated problem [4]. Metacognition is developed by implementing the internal psychological skill of students and optimizing the learning process, which is supported by the management use of learning models [5]. Project-based learning (PjBL) is one of the alternative methods used to acquire this skill set.

PjBL is a learning method which supports metacognition skills and increases students' learning involvement. Additionally, it provides a different learning experience in the following stages: 1) essential questions, 2) project planning, 3) timeline making, 4) project observation, 5) 
outcome measurement, and 6) evaluation process [6], [7]. This stage has some metacognition sub-stages, which are 1) specifying goals, 2) monitoring process, 3) clarity, and accuracy. In addition, PjBL is a long-term learning process, which involves the making and display of products related to the solution of real-life problems, to students [8]. It focuses on the daily problem solving through hands-on practice [9]-[11]

Previous studies have successfully measured the effect of PjBL, namely learning outcomes and motivation, problem-solving skills, creative thinking process, leadership abilities, and communication skills. It does not only increase students' motivation but also facilitates their problem-solving skills [12], thinking creativity and positive behavior [13]. The implementation of PjBL significantly increases the high level of cognitive, self-efficacy, teamwork, and communication skills [14].

In previous studies, $\mathrm{PjBL}$ was a standalone learning model with knowledge content. However, it is currently an integrative multidiscipline skill called integrated-project based learning (I-PjBL). It also increases their motivation and learning interest [15]. An integrative approach focuses on the theme chosen as the main project, considering students' learning characters which are mostly holistic during the pre-operational concrete phase. The themes chosen are water cycle, making slime, making ice cream, and making batik jumputan which consist of substances, material, mixture stuff, alternative energy, as well as arts and cultures.

The I-PjBL stages consist of many advantages which tend to increase motivation, learning behavior, attitude, and preference [16]. It also pushes teachers to carry out important jobs using their problem-solving skills through collaborative activities. It allows students to develop their communication, information literacy, and IT skills [17], [18]. In addition, students are trained to manage their learning source, time, and tools while working on projects. I-PjBL plays a huge role in supporting the realization of meaningful and pleasant learning environment which enables students and teachers to enjoy the process [19], [20]

I-PjBL increases metacognition skills which is the second-highest skill after factual, conceptual, and procedural knowledge [20], [21]. It is also defined as a way of thinking as well as cognitive process and often associated with reflective behavior and self-awareness [22]-[24]. I-PjBL contributes to three sub-domains of self-regulated learning models, which are internal motivation (13\%), willingness to finish homework (7\%), and metacognition experience (4\%) [25], [26].

Metacognition consist of two parts, namely knowledge and regulation [27]-[29] Cognitive knowledge comprises of 1) declarative knowledge on oneself and strategy; 2) procedural knowledge which focuses on how people use their strategy in learning; 3) conditional knowledge which focuses on when and why people utilize these strategy.
Meanwhile, cognitive regulation utilizes individual skills, such as 1) goal planning to achieve setting goals; 2) information management strategy which includes skills and strategy of someone to efficiently manage, summarize, and sort out information; 3) understanding observation and acknowledge self-awareness to master the material and use the strategy effectively; 4) conformity of the strategy to fix the errors during understanding process; and 5) evaluation of the learning strategy previously selected [22], [30]-[32].

This study attempted to mix all metacognition skills based on its taxonomy [29], [33], [34]. Its variable was closely related to students' thinking style, which was why gender contributed to a person's metacognition pattern. It also aimed to analyze the metacognition skill of students through the I-PjBL intervention and to measure their differences based on gender.

\section{Research Questions}

1. How was the metacognition condition of the students who studied using the I-PjBL model?

2. Are there any metacognition differences among the students due to the I-PjBL intervention?

3. How were the metacognition differences among male and female students?

\section{Methods}

\subsection{Research Method}

The study was a quasi-experimental design with a single-group pretest-posttest design. A total of 33 fifth grade students comprised of 16 males and 17 females, selected through simple random sampling. I-PjBL treatment was conducted after obtaining 4 time-different results which was followed by a post-test to obtain metacognition data from the participants. Students' activities during I-PjBL can be shown in Table 2 .

The selection of this design was adjusted to the purpose of the study which was to find out the impact of I-PjBL on students' metacognition. Students worked on the pretest, then given treatment in the form of I-PjBL, then they did the posttest. Every meeting in I-PjBL, students were observed to analyze their progress during treatment.

\subsection{Ethical Clearance}

This study was approved by the Ahmad Dahlan University Ethics Committee (EC Number 011905048). The recommendations leading to the instruments used in this study need to be adjusted to the development level of students under the age of 17 to ensure the questionnaire comprised of "yes" and "no" answers in accordance with the Guttman scale. The informed consent was signed by 
parents, with EC evidence used as part of the articles supplement.

\subsection{Variables}

This study consisted of one independent variable, one moderator variable, and one dependent variable. Independent variable is I-PjBL learning method. Moderator variable is genres that are male and female, and dependent variable is metacognition. The specific impact of I-PjBL intervention is determined by measuring every aspect of the metacognition, namely Knowledge and Regulation.

\subsection{Data Collection}

This study used three data collection techniques, namely observation, documentation, and Metacognition Awareness Inventory (MAI) to determine its Guttman Scale[29], with observation guidance used by 3 analysis to determine the suitability of the design and implementation of I-PjBL. The documentation consisted of a lesson plan, students' worksheet, photos, and videos during the lesson. The MAI adopted in this study [29] consisted of indicators as shown in Table 1.

This study used the face and construct validity (content and empiric), with the face validity conducted by experts to examine the readability of statements and suitability of the terms. Content validity was conducted to determine the suitability of statements and indicators, and empirical validity was assigned for students to determine the instrument capability in measuring variables. The MAI questionnaire was validated by conducting a field test towards 30 students in their 5th grade. This was further processed using the point biserial correlation formula. MAI questionnaire consisted of $\mathbf{1 7}$ valid statements, with the reliability test calculated by using the Alpha Cronbach formula to obtain $\mathrm{R}=0,929$.

Table 1. Indicator of Metacognition Awareness Inventory (MAI)

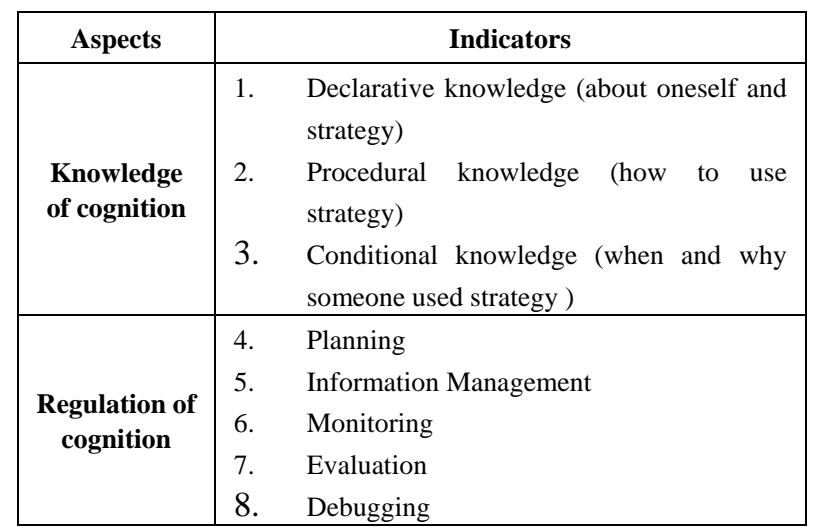

Table 2. Students' activities during I-PjBL

\begin{tabular}{|c|c|c|c|}
\hline Activities & Types of Project & Material & Students' responses \\
\hline Meeting 1 & - & Pretest & Working on the MAI pre-test \\
\hline Meeting 2 & $\begin{array}{l}\text { Rain simulation to learn } \\
\text { about the water cycle }\end{array}$ & & $\begin{array}{l}\text { The students were enthusiastic on arranging a rain simulation with } \\
\text { their groups. }\end{array}$ \\
\hline 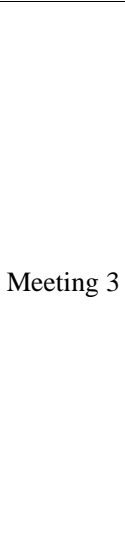 & 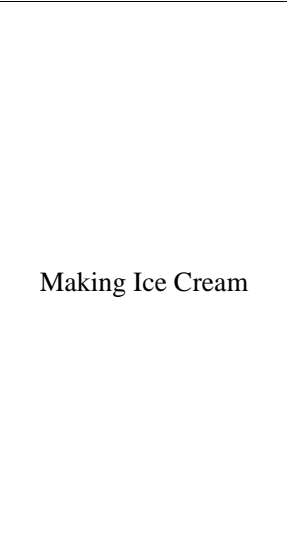 & $\begin{array}{l}\text { The concept of } \\
\text { single and mix } \\
\text { substances }\end{array}$ & $\begin{array}{l}\text { The students were happy and enthusiastic to make ice cream from } \\
\text { water, syrup, and jelly. They brought the ice cream home to be } \\
\text { frozen. } \\
\text { Figure 2. Students are Collaborating to Make Ice Cream }\end{array}$ \\
\hline
\end{tabular}




\begin{tabular}{|c|c|c|c|}
\hline Meeting 4 & Making slime & $\begin{array}{l}\text { Single and mix } \\
\text { substances }\end{array}$ & $\begin{array}{l}\text { The enthusiasm of students during the activity is seen when } \\
\text { making a mistake in mixing the ingredients. Some slime was } \\
\text { too runny or too dense, and they tried to put the ingredient } \\
\text { based on their recipe till the perfect slime was observed. }\end{array}$ \\
\hline & & & Figure 3. The Students were Collab \\
\hline Meeting 5 & Making Batik jumputan & Mix substances & $\begin{array}{l}\text { Figure 4. The Enthusiasm of Students During the Activity } \\
\text { While were making batik jumputan, the students were given } \\
\text { a chance to express their ideas. The patterns were made by } \\
\text { tying the marbles to the batik. They mixed the dyes and dip } \\
\text { the white cloth till the color was absorbed. The bound } \\
\text { marbles gave a particular pattern while absorbing the cloth. } \\
\text { After the ties untied, beautiful and colorful batik jumputan } \\
\text { was formed and the pattern was based on students' } \\
\text { creativity. Their enthusiasm was seen at the end of the } \\
\text { session when they asked after the next project. } \\
\text { a }\end{array}$ \\
\hline Meeting 6 & - & Post-test & Working on a MAI post-test. \\
\hline
\end{tabular}




\subsection{Data Analysis}

This study used the Kolmogorov-Smirnov SPSS 22 formula for the normality test, the Fisher test to determine homogeneity. The result of the normality and homogeneity test indicated that the sample was not normal but homogenous and required a non-parametrical test. The first question was analyzed using the descriptive statistic, with Wilcoxon Signed Ranks Test used to analyze the hypothesis of the second question. Furthermore, Mann Whitney $U$ was used to analyze the hypothesis of the third question.

\section{Findings}

\subsection{Normality Test}

Kolmogorov-Smirnov was used as a normality test of this study. The criteria used to determine the normality of the data was $\mathrm{p}>0.05$ (normal) and $\mathrm{p}<0.05$ (abnormal), with the result provided in Table 3 .

Table 3. Normality Test

\begin{tabular}{|c|c|c|}
\hline Variable & Sig & Conclusion \\
\hline knowledge & 0.008 & Abnormal \\
\hline regulated & 0.000 & Abnormal \\
\hline metacognition & 0.008 & Abnormal \\
\hline
\end{tabular}

Table 4 showed that the prerequisite test of normality failed to meet the criteria due to data abnormality. Its transformation (Ln, Log, SQRT) which was conducted to deal with this condition, showed same result. Therefore, a non-parametrical test was conducted which does not require the assumption fulfillment of the parametric.

\subsection{Homogeneity Test}

The criteria used for homogeneity test

Table 4. Test of Homogeneity of Variance

\begin{tabular}{|c|c|c|}
\hline Variable & $\begin{array}{c}\text { Sig (Based on } \\
\text { Mean) }\end{array}$ & Conclusion \\
\hline knowledge & 0,781 & Homogeneous \\
\hline regulated & 0,290 & Homogeneous \\
\hline metacognition & 0,353 & Homogeneous \\
\hline
\end{tabular}

Table 4 showed the homogeneity of the three variables, with a hypothesis test conducted for the next step.

\subsubsection{Research Question 1}

How was the metacognition skill of those that studied with the I-PjBL model?

The metacognition skill of those that studied with the I-PjBL model were analyzed using descriptive statistics. The result was shown in Table 5.
Table 5. Description of Student's Metacognition Skill

\begin{tabular}{|c|c|c|}
\hline & pretest & posttest \\
\hline $\mathrm{N}$ & 33 & 33 \\
\hline Mean & 12,24 & 14,48 \\
\hline Median & 13,00 & 15,00 \\
\hline Mode & $9^{\mathrm{a}}$ & 18 \\
\hline Std. Deviation & 3,153 & 2,970 \\
\hline Minimum & 7 & 8 \\
\hline Maximum & 17 & 18 \\
\hline
\end{tabular}

a) Multiple modes exist. The smallest value was shown

The mean of metacognitive posttest was higher than the pretest with a difference of 2,24, which is cumulative for metacognitive variables. However, this figure is unable to significantly describe the impact of the I-PjBL intervention on metacognition skills, therefore, it is necessary to test the hypotheses in questions 2 and 3.

\subsubsection{Research Question 2}

Are there any metacognition differences among students before and after I-PjBL intervention?

The relationship between I-PjBL and metacognition skill along with its aspects was analyzed using two related samples test. The result was shown in Table 6 .

Table 6. The result of two related samples by using Wilcoxon Signed Rank Test

\begin{tabular}{|c|c|c|c|}
\hline & \multicolumn{3}{|c|}{ Posttest - Pretest } \\
\hline Variable & Metacognition & $\begin{array}{c}\text { Knowledge of } \\
\text { cognition }\end{array}$ & $\begin{array}{c}\text { Regulated of } \\
\text { cognition }\end{array}$ \\
\hline $\mathrm{Z}$ & $-2.107^{\mathrm{b}}$ & $-.072^{\mathrm{b}}$ & $-2.490^{\mathrm{b}}$ \\
\hline $\begin{array}{c}\text { Asymp. Sig. } \\
\text { (2-tailed) }\end{array}$ & .035 & .942 & .013 \\
\hline \multicolumn{2}{|l|}{ a. Wilcoxon Signed Ranks Test } \\
\hline \multicolumn{4}{|l}{ b. Based on negative ranks. } \\
\hline
\end{tabular}

Table 6 shows that in the metacognition variable, the $\mathrm{Z}$ value obtained was -2.107 and $\mathrm{p}$ (Asymp. Sig 2 tailed) was $0.035<\alpha(5 \%)$. Therefore, $\mathrm{H}_{1}$ was accepted, it means that there were significant differences between the pretest and posttest groups. In the Knowledge aspect of cognition, the $\mathrm{Z}$ value obtained was -0.072 , while the $\mathrm{p}$-value (Asymp. Sig 2 tailed) was $0.942>\alpha(5 \%)$, therefore $\mathrm{H}_{1}$ was rejected. This means that there was no significant difference between the pretest and posttest groups. In the Regulated Cognition aspect, the $\mathrm{Z}$ value obtained was $-2,490$ and p-value (Asymp. Sig 2 tailed) was $0.013<\alpha(5 \%)$ therefore, $\mathrm{H}_{1}$ was accepted, with a significant difference between the pretest and posttest groups.

\subsubsection{Research Question 3}

How was the metacognition difference among male and female students after I-PjBL implementation?

In this part, the metacognition differences among male 
and female students due to I-PjBL intervention were analyzed using Mann-Whitney U. It was separated into three parts which consists of sex analysis towards 1) metacognition; 2) knowledge of cognition; 3) the regulation of knowledge. The result was shown in Table 7.

Table 7. Hypothesis Test Result of Metacognition Differences in Male and Female Students

\begin{tabular}{|c|c|c|c|}
\hline & metacognition & knowledge & regulated \\
\hline Mann-Whitney U & 103.000 & 373.000 & 347.000 \\
\hline Wilcoxon W & 1756.000 & 2026.000 & 2000.000 \\
\hline Z & -7.848 & -6.053 & -6.185 \\
\hline Asymp. Sig. (2-tailed) & 0.000 & 0.000 & 0.000 \\
\hline
\end{tabular}

Based on Table 7, the significance of the p-value at $0.000<0.05$, means that the null hypothesis (Ho) was rejected due to the differences caused by the I-PjBL implementation among male and female students. In addition, the differences were also found in the knowledge and regulated cognition components of male and female students.

\section{Discussion}

This study involved 33 students provided with I-PjBL intervention with the projects integrated. The teachers delivered the steps of I-PjBL learning and the students follow suit. They also divided the class into 6 smaller groups, with both parties allowed to explore the information to be used in the $2^{\text {nd }}, 3^{\text {rd }}, 4^{\text {th }}$, and $5^{\text {th }}$ meeting.

In the second meeting, the lesson was on water cycle, with the students allowed to produce a product of rain simulation. The third meeting discussed single and mix substances which were followed by an ice cream making project. The lesson provided in the fourth meeting was single and mix substances. This time, the students provided slime with their color and textures. In the fifth meeting, they discussed mix substances by making batik jumputan with the use of marbles. They also made a group and observed the process of stain mixing with water.

The I-PjBL method strongly supports students' skills. It helped them to make a plan to finish their project, divided their assignment, prepared stuff and material, arranged timeline, worked on the project, presented and evaluated the result, which fostered their metacognition skills [35], [36] In the planning stage, the students were trained to be aware of their purpose to determine a suitable strategy to reach their goal and to be aware of their responsibility in the group. In the implementation stage, they were guided to monitor their activities. The process of finding the concepts and constructing the knowledge was conducted with the help of teachers through product making experiences. In the evaluation stage, the students were trained to be reflective. Both teachers and students reflected their learning outcomes through the strategies chosen by the students. The aspect of independence in I-PjBL was closely related to metacognition [35]. Collaboration activities pushed the students to give and accept feedback on their performance, which became an important component in increasing their metacognition skills.

To achieve success, the learning environment and teaching practice were made to support student-regulated learning (SRL) [36]. The students were responsible for the process by setting goals, observing, reflecting, and maintaining their motivation from the beginning to the end of the project. Learning projects in form of scientific internships supports the understanding of the content, student involvement, and confidence in applying science [37].

I-PjBL has the ability to train students to be critical and creative, to emphasize on their activity in solving various open-ended problems and apply their knowledge to work on a project to create authentic outcomes. Through I-PjBL, they are able to create something, and make report on it using their creative thinking ability which gave them a chance to learn autonomously, and constructs to work using real-life situation. I-PjBL provided with fun and meaningful learning. The metacognition of the students was in the form of high order thinking activities which controlled their thinking process with a proper strategy capable of optimizing their learning process.

I-PjBL process overlapped with the components of metacognition, which were knowledge (declarative, procedural, and conditional) and regulation (planning, information management, monitoring, evaluating, and debugging). Theoretically, good cognition knowledge had the ability to make the students determine the purpose of the study. The students were able to choose the best strategy to reach their goals as long as they controlled their performance and evaluated their achievement [38]. However, this study gave a different result by showing that I-PjBL failed to simultaneously affect the two components. It only fully affected the metacognition and regulated aspects, and it did not give different results in the knowledge aspect. This was because cognition knowledge was one of students' self-modalities which were not easily influenced by external factors such as learning models.

Cognition knowledge consists of declarative, procedural, and conditional knowledge, which was strongly influenced by students' ability to recognize their potentials. The ability of self-assessment of elementary school students was no better than the upper level, which was a major reason for its training. I-PjBL failed to accommodate this stage with the process of identifying goals, assignments, and learning strategies under the guidance of teachers. Furthermore, they were guided to recognize their learning styles to determine the best strategy capable of supporting and maximizing the process. Learning styles had an impact on critical thinking skills. For example, Abstract Sequential learners tend to show better critical thinking than Abstract Random, Concrete Sequential, and Concrete 
Random learners [39].

Another finding from this study was the different metacognition abilities of male and female students. This difference is seen from the significance of $<0.05$ in all aspects of metacognition (knowledge and regulated) and intact variables. This difference tends to be caused by the learning style which differs in men and women. In general, men preferred traditional education while women did not find the same result [40], [41]. Patterns of differences in sex-based learning styles were observed, and teachers were encouraged to consider the strength of the students' learning style to maximize its outcomes [42].

I-PjBL applied in the experiment began with a preliminary activity where teachers explained the scenario to be implemented by students. They prepared themselves after knowing their learning goals and assignments. The students were then invited to study the water cycle, single, homogeneous and heterogeneous substances. The teachers and students explored the material by discussions, books, and direct explanation. Questions related to the project where given to the students by the teachers, in a worksheet, with the answers and best solutions to the problems provided on the material. After that, the students determined the project and worked on it based on the material discussed. They designed and collected products, tools, and materials and worked in groups. The teacher, as a motivator, was in charge of directing and coordinating the activities to keep it on track. At this stage, they assessed students' metacognition and encouraged them to take responsibility for the activities. In the final stage, the teachers and the students concluded and evaluated the activities, which was also a reflection of students' activities towards the learning process and outcomes.

I-PjBL faced some constraints during its implementation, such as long duration needed for making the project design. Although students were enthusiastic about participating, they were not accustomed to working on the stages independently. They sometimes asked for help from the teacher, which made the teacher's role dominant in guiding students to work on the project. The implementation of I-PjBL required a number of principles which need to be considered by teachers, namely: 1) time management (project scheduling), 2) preparation (directing students to think of projects long before they start), 3) Culture building which emphasized student self-management (transfer responsibility from the teacher to students to design the projects, make decisions, and learn), 4) student group management (trace the group progress through discussion, monitoring, and progress report); 5) collaboration to work with others outside the classroom (other teachers, parents, community), 6) technology utilization, 7) students' assessment and project evaluation (through various reflective strategies on the projects) [43].

In maximizing the implementation of I-PjBL, several important aspects were recommended for school management;
1) Student support: Students need to be effectively guided and supported with emphasis on time and self-management, along with the search for effective learning resources. Student learning styles strongly determined the metacognition strategies in implementing I-PjBL.

2) Teacher support: teachers need to build networks and competencies regularly with effort to improve quality through lesson studies.

3) Effective group work: high-quality group work tends to increase the positive involvement of students.

4) Clear instructions from teachers has the ability to help students set their work patterns.

5) The emphasis of assessment on periodic reflection, self-evaluation, and peers.

6) Students' independence during the PBL process has the ability to help students develop a sense of ownership and control over their learning process [43].

\section{Conclusions}

Based on the results and discussion, it is concluded that students possessed metacognition differences before and after the I-PjBL intervention. However, there was no difference in terms of cognition knowledge, with a difference found in its regulation. In the sex variable, there were significant differences in the metacognition skills, knowledge, and of the regulation of male and female students' cognition skills. In addition to external factors such as the intervention of the I-PjBL model, metacognition was affected by internal factors including student motivation, thinking and learning style, as well as other factors that supported the success of the learning process. Some aspects that need to be considered in implementing the I-PjBL were student and teacher support, the effectiveness of group work, clear instructions from teachers, with emphasis on student reflection and evaluation through periodic self-assessments, and their independence.

\section{Acknowledgements}

The authors are grateful to the ministry of research, technology, and higher education of Indonesia for funding this study through the PTUPT scheme.

\section{Conflict of Interest}

This research was proposed by the Ministry of Research, 
Technology and Higher Education funding and can be directed to the development of products that can be licensed to Ahmad Dahlan University, where I have an academic interest. I have expressed these interests for Ahmad Dahlan University, and have had a plan that supports every potential conflict that arises from this arrangement.

\section{REFERENCES}

[1] S. Zubaidah, N. M. Fuad, S. Mahanal, and E. Suarsini, "Improving Creative Thinking Skills of Students through Differentiated Science Inquiry Integrated with Mind Map," J. Turkish Sci. Educ., vol. 14, no. 4, pp. 77-91, 2017.

[2] M. A. de los Clemente, "Learning Cultures and Counselling: Teacher/Learner Interaction within a Self-Directed Scheme," Learner Autonomy across Cultures. Palgrave Macmillan UK, pp. 201-219, 2003.

[3] P. H. Winne, Cognition and metacognition with- in self-regulated learning. New York, NY: Routledge, 2018.

[4] E. Eriawati and K. Khairil, "Aplikasi Metakognitif dalam Keterampilan Monitoring pada Konsep Ekosistem,” J. Edubio Trop., vol. 1, no. 1, 2013.

[5] M. Peñafiel, S. Vásquez, and S. Luján-Mora, "Use of Virtual Classroom: Summarized Opinion of the Stakeholders in the Learning-Teaching Process," Proceedings of the 8th International Conference on Computer Supported Education. SCITEPRESS - Science and and Technology Publications, 2016.

[6] L.-C. Chang and G. C. Lee, “A team-teaching model for practicing project-based learning in high school: Collaboration between computer and subject teachers," Comput. Educ., vol. 55, no. 3, pp. 961-969, Nov. 2010.

[7] W. A. Lucas and S. Barge, "Effects of Project-based Practice on Self-efficacy and the Pursuit of Engineering Studies," in Proceedings of the 21st Annual Conference for the Australasian Association for Engineering Education, 2010, p. 691.

[8] R. A. Sani, Pembelajaran Saintifik untuk Implementasi Kurikulum 2013. Jakarta: Bumi Aksara, 2017.

[9] R. Eskrootchi and G. R. Oskrochi, “A Study of the Efficacy of Project-based Learning Integrated with Computer- based Simulation - STELLA,” J. Educ. Technol. Soc., vol. 13, no. 1, pp. 236-245, 2010.

[10] I. Bilgin, Y. Karakuyu, and Y. Ay, "The effects of project based learning on undergraduate students' achievement and self-efficacy beliefs towards science teaching," Eurasia J. Math. Sci. Technol. Educ., vol. 11, no. 3, pp. 469-477, 2015.

[11] C. S. Johnson and S. Delawsky, "Project-based learning and student engagement,” Acad. Res. Interanational, vol. 4, no. 4, pp. 560-571, 2013.

[12] C. L. Chiang and H. Lee, "The Effect of Project-Based Learning on Learning Motivation and Problem-Solving
Ability of Vocational High School Students,” Int. J. Inf. Educ. Technol., vol. 6, no. 9, pp. 709-712, 2016.

[13] S. Mihardi, M. B. Harahap, and R. A. Sani, "The Effect of Project Based Learning Model with KWL Worksheet on Student Creative Thinking Process in Physics Problems,” J. Educ. Pract., vol. 4, no. 25, pp. 188-200, 2013.

[14] E. H. Fini, F. Awadallah, M. M. Parast, and T. Abu-Lebdeh, "The impact of project-based learning on improving student learning outcomes of sustainability concepts in transportation engineering courses,” Eur. J. Eng. Educ., vol. 43, no. 3, pp. 473-488, May 2018.

[15] J. Afriana, A. Permanasari, and A. Fitriani, "Project Based Learning Integrated STEM to Enhance Elementary School Student Scientific Literacy,” J. Pendidik. IPA Indones., vol. 5, no. 2, pp. 261-267, Nov. 2016.

[16] S. Dole, L. Bloom, and K. K. Doss, "Engaged Learning: Impact of PBL and PjBL with Elementary and Middle Grade Students,” Interdiscip. J. Probl. Learn., vol. 11, no. 2, Jul. 2017.

[17] J. Ravitz, J. Blazevski, S. K. W. Chu, S. . Tse, and K. Chow, "Using collaborative teaching and inquiry project-based learning to help primary school students develop information literacy and information skills,” Libr. Inf. Sci. Res., vol. 33, no. 2, pp. 132-143, Apr. 2014.

[18] J. Ravitz and J. Blazevski, “Assessing the Role of Online Technologies in Project-based Learning,” Interdiscip. J. Probl. Learn., vol. 8, no. 1, Apr. 2014.

[19] F. Musa, N. Mufti, R. A. Latif, and M. M. Amin, "Project-based Learning: Promoting Meaningful Language Learning for Workplace Skills,” Procedia - Soc. Behav. Sci., vol. 18, pp. 187-195, Jan. 2011.

[20] S. R. Tamim and M. M. Grant, "Definitions and Uses: Case Study of Teachers Implementing Project-based Learning," Interdiscip. J. Probl. Learn., vol. 7, no. 2, May 2013.

[21] F. Radmehr and M. Drake, “Revised Bloom’s taxonomy and integral calculus: unpacking the knowledge dimension,” Int. J. Math. Educ. Sci. Technol., vol. 48, no. 8, pp. 1206-1224, Nov. 2017.

[22] J. H. Flavell and D. H. Schunk, "Metacognition and cognitive monitoring: A new area of cognitive-developmental inquiry.,” Am. Psychol., vol. 20, no. 10, pp. 463-467, Dec. 2008.

[23] G. Schraw, "Promoting general metacognitive awareness," Instr. Sci., vol. 26, no. 1/2, pp. 113-125, 1998.

[24] D. H. Schunk, "Metacognition, Self-Regulation, and Self-Regulated Learning: Research Recommendations," Educ. Psychol. Rev., vol. 20, no. 4, pp. 463-467, Dec. 2008.

[25] Z. Ç. Özcan, “The relationship between mathematical problem-solving skills and self-regulated learning through homework behaviours, motivation, and metacognition,” Int. J. Math. Educ. Sci. Technol., vol. 47, no. 3, pp. 408-420, Apr. 2016.

[26] R. A. Sperling, B. C. Howard, R. Staley, and N. DuBois, "Metacognition and Self-Regulated Learning Constructs," Educ. Res. Eval., vol. 10, no. 2, pp. 117-139, Apr. 2004.

[27] D. Moshman, “Metacognitive Theories Revisited,” Educ. 
Psychol. Rev., vol. 30, no. 2, pp. 599-606, Jun. 2018.

[28] Y. Jiang, L. Ma, and L. Gao, “Assessing teachers' metacognition in teaching: The Teacher Metacognition Inventory,” Teach. Teach. Educ., vol. 59, pp. 403-413, Oct. 2016.

[29] G. Schraw and R. S. Dennison, “Assessing metacognitive awareness,” Contemp. Educ. Psychol., vol. 19, no. 4, pp. 460-475, 1994.

[30] G. Schraw, L. Olafson, M. Weibel, and D. Sewing, "Metacognitive Knowledge and Field-based Science Learning in an Outdoor Environmental Education Program," in Metacognition in Science Education, Springer, Dordrecht, 2012, pp. 57-77.

[31] N. S. Wilson and H. Bai, "The relationships and impact of teachers' metacognitive knowledge and pedagogical understandings of metacognition,” Metacognition Learn., vol. 5, no. 3, pp. 269-288, Dec. 2010.

[32] M. Caliskan and A. M. Sunbul, "The Effects of Learning Strategies Instruction on Metacognitive Knowledge, Using Metacognitive Skills and Academic Achievement (Primary Education Sixth Grade Turkish Course Sample),” Educ. Sci. Theory Pract., vol. 11, no. 1, pp. 148-153, 2011.

[33] B. J. Zimmerman, "Self-Regulated Learning and Academic Achievement: An Overview,” Educ. Psychol., vol. 25, no. 1, pp. 3-17, Jan. 1990.

[34] A. Efklides, "Interactions of Metacognition with Motivation and Affect in Self-Regulated Learning: The MASRL Model,” Educ. Psychol., vol. 46, no. 1, pp. 6-25, Jan. 2011.

[35] L. Dörr and F. Perels, "Improving Metacognitive Abilities as an Important Prerequisite for Self-Regulated Learning in Preschool Children,” Int. Electron. J. Elem. Educ., vol. 11, no. 5, pp. 449-459, Jul. 2019.

[36] R. Ergul, Y. Simsekli, S. Calis, Z. Ozdilek, S. Gocmenceleebi, and M. Sanli, "The Effect of Inquiry-Based Science Teaching on Elementary School Students' Science Process Skills and Science Attitudes,” Bulg. J. Sci. Educ. Policy, vol. 5, no. 1, pp. 48-68, 2011.

[37] T. D. Sadler, S. Burgin, L. McKinney, and L. Ponjuan, "Learning science through research apprenticeships: A critical review of the literature,” J. Res. Sci. Teach., vol. 47, no. 3, pp. 235-256, 2010.

[38] J. E. Mills and D. F. Treagust, "Using Project to Teach Structural Engineering,” Aust. J. Eng. Educ., vol. 9, no. 2, pp. 211-220, 2003.

[39] B. E. Myers and J. E. Dyer, "The Influence of Student Learning Style On Critical Thinking Skill,” J. Agric. Educ., vol. 47, no. 1, pp. 43-52, 2006.

[40] M. Philbin, E. Meier, S. Huffman, and P. Boverie, "A Survey of Gender and Learning Styles,” Sex Roles, vol. 32, no. 7-8, pp. 485-494, Apr. 1995.

[41] R. Riding and M. Grimley, "Cognitive Style, Gender and Learning from Multi-Media Materials in 11 - year - old Children,” Br. J. Educ. Technol., vol. 30, no. 1, pp. 43-56, Jan. 1999.

[42] C.-C. Tsai, S.-C. Chuang, J.-C. Liang, and M.-J. Tsai, "Self-efficacy in Internet-based Learning Environments: A
Literature Review,” J. Educ. Technol. Soc., vol. 14, no. 4, pp. 222-240, 2011.

[43] D. Kokotsaki, V. Menzies, and A. Wiggins, "Project-based learning: A review of the literature,” Improve. Sch., vol. 19, no. 3, pp. 267-277, 2016. 